30

「帯喼コンタクトレンズによる

眼球運動の無拘束計測システムの開発」

鎮西清行、土肥健純、增沢徽”、喜多村健“ 東京大学工学部 精密機械工学科 東京電機大学理工学部 応用電子工学科 東京大学医学部 耳鼻咽喉科

1. はじめに

平衡感賞異常に上了症状の一つとして、眼振 がちる。眼振計測法として現在、最も一般的な の注眼電位計測法（EOG，また法ENGと路

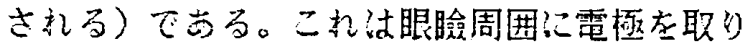
付讨、その電位夻計測するむのでる。この方 法はシステムが簡単て、広く普及しているが、 電極出力が不安定兄なり易い。12

この他の方法として、外部から与えた交流酳 界药コンタクトレンズに組承迄んだ誘導コイル への起電力として榆出する方法が台る ${ }^{3}$ 。安定 した出力が得ら机るが、コイルがコンタトレ ンスとして注大きく（值径約 $18 \mathrm{~mm}$ ）、またコ

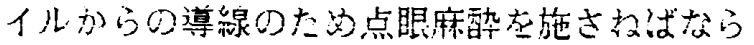
效。さらに、導線が眼球のスムーズ去媈動を 阻害寸る億念加苛る。

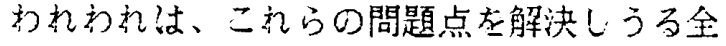
く新し、眼球運動計測システム先開発した。

\section{2. 本システムの原理、演算法}

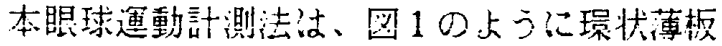
状の永久磁石組子迅んだコンタクトレンスを 眼球:装着し、气の屰界太眼鏡等:装着した複 数の㗶気センサで検出寸万方法である。

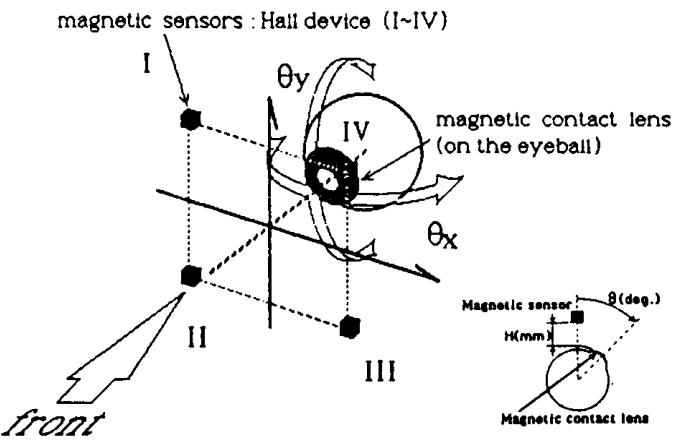

因 1：ホール素子七带磁性コンタクト

レンズの䍐置と座標系

眼球運動にとも就!磁石の位置が变化するとそ の変化渭々のセンサ位置での磁束密度の変化 として検出される。角膜頂点から磁気センサま での距離 $\mathrm{H}$ と、センサと眼球中心を結ぶ軸と磁

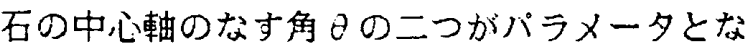
る。各センサ出力から、各センサについての 在求为、 $\theta$ ?関し演算処理左行い、眼球の回転 角求好るのでちる。
3.シフテム構成

シフテム構成太图2示す。

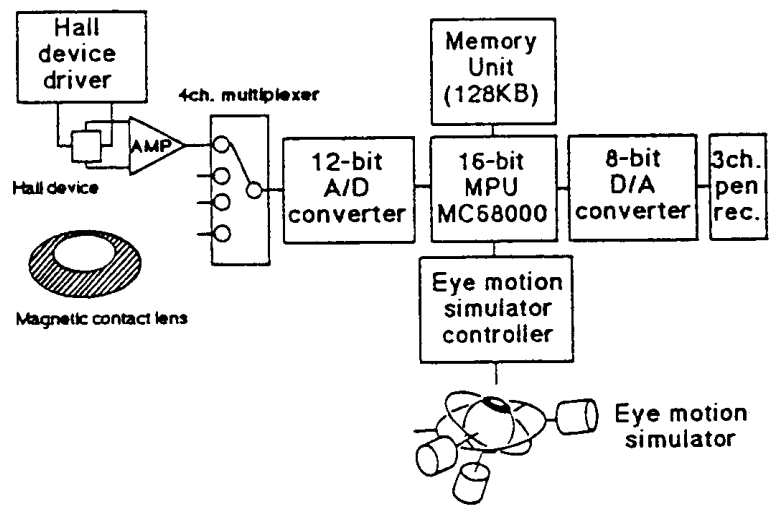

図2:システムブロッ罗

帯證コンタクトレンス゚の磁石部は、半径7. $8 \mathrm{~mm}$ 、厚子 $0.1 \sim 0.2 \mathrm{~mm}$ 球面应外径 11 $\mathrm{mm}$ 、内经 $6 \mathrm{~mm}$ :切り抜いた形状とする。費用の 点から、磁石製作长型成形で行えないた鸟、実 駼:用、た酸石沈Ba采磁性粉体をアクリ儿采 樹脂に混合した素材方方研削に上り製作した。

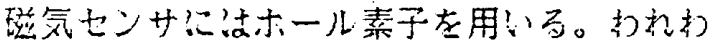
㣗の用いたホール素子は一辺 $2 \mathrm{~mm}$ 程の立方体て、 それ不眼鏡等に固定する。

セン出力应約 1 万倍增幅した後、 $\mathrm{A} / \mathrm{D}$ コンバータ长経て16ビットマイクロブロセッ サ兄て、眼球の変位角方計算さ放る。

この他:システム開発用に眼球の運動機满在 模したモー夕制御可能㐫直交了蟿ジャイロ機構 加学3「眼球運動シミコレー多」龙製作し、 本装置に磁石应装着して各種䒠駼长行った。

\section{4. 結果並ざ?検討}

1. 1 実騃データの処理法

本来、実用:供寸る帯磁コンタクトレンズ就 前述した上う球面状て吉るから、実験にも球

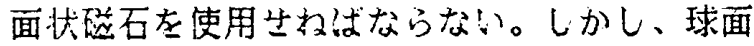
壮研削长行う加工条件設定が難しく、破損が相 次いだため、先:添泀同寸の平面環状の磁五（ 外径 $13 \mathrm{~mm}$ 、内径 $5.5 \mathrm{~mm}$ 、厚發 $0.2 \mathrm{~mm}$ ) を 製作し、実駼に使用した。

従って考察左行うため、この平面状磁石を用 いて得られた実験結果から、球面状磁石立用い て実駼を行った場合得ら忋る結果を推定する必 要がうる。このため心注、両者の特性の問の関 倸を知亏必要がある。そこで数值計算により両 者同じ条件での磁束密度特性を求めた。磁石を 溦少な磁石の集合と考元、全体の磁束密度を、 その和として求めた。その样子を図 $3 に$ 示す 

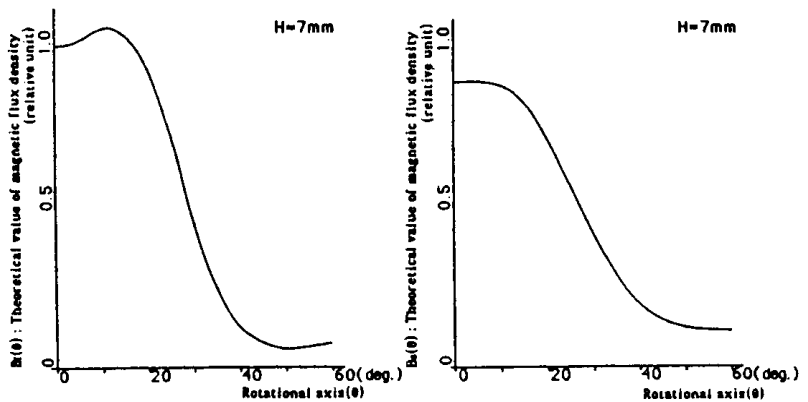

因 3：数値計算心上及平面レンス（左）。 球面レンズ（右）の磁束滵度つ推定

4.2シミコレータによる平面状形石の磁 束密度の测定

平面状应石を「眼球運動シミュレータ」に装 着して、数値計算結果の国3のグラつと同漾の 条件にした場合のセンサ出力在测定し、8!つ いてプロットした。その結果が图4で苛る数 值計算に上当推定の有効性が示される。

\section{3球面状磁石の磴束密度の算出}

平面状磁石の磁束密度の数値計算結果と球面 壮琶石の礠束密度の数値計算結果を $\theta=45$ の点を基準として比較した。平面状磁石の場合 の实测結果と数値計算結果の問の比方球面状政 无の場合むそのまま成り立つと考之、球面状琣 石心磁束密度推定を行った。その結果方图らて ある。

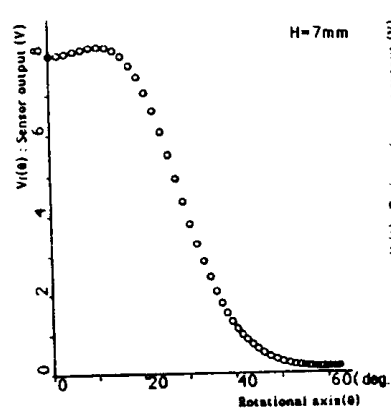

四4：平面レンズの 磁束密度测定結果

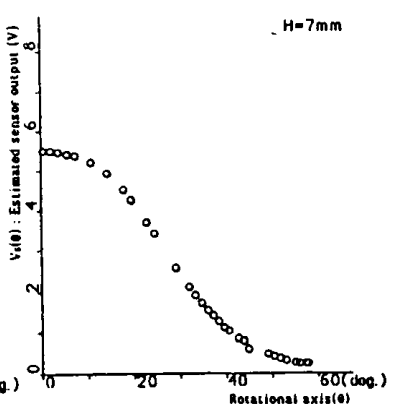

因5：球面しンズの 磁密度則定站果 の推定(Vs)
球面レンズの推定出力Vs ( $\theta$ )は以下の

式加的求女た。

$V s(0)-V_{s}(45)=\frac{B s(\theta)-B s(45)}{B f(\theta)-B f(45)} \times\{V f(0)-V f(45)\}$

Bs:球面レンズ束密度計算結果 Bf:平面レンズ碳密度計算結果 Vf:平面レンズ出力実則㰴果

\section{4，本方式:上る眼球運動計測箸囲}

われちれの製作したシステムではセンサ信号 の直流増幅率が高いことお岕って、士 $10 \mathrm{mV}$ 程のノイズが存在する。そして、センサ出力 out から日龙める際、V out の分解能がこの ノイズ值に上り制限される。要求される計测分 解能在 $1^{\circ}$ とするなら、図5から、有効な日の 得ら亲範围は、 $\theta=9.5^{\circ} \sim 43^{\circ}$ となる センサ間の角度药 $50^{\circ} 、 \mathrm{H}=7 \mathrm{~mm}$ とした場合

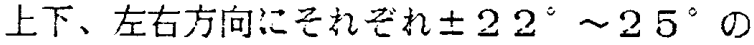
計测域在得ること方可能た出る。

眼振計㓯では土 30 “程度の計测域を必要と することがあるので、この結果てはまだ不完全 でるが、櫭衫满足できる特性が得られる。

\section{5. 今後心展望}

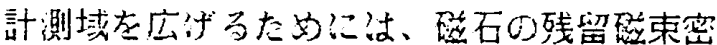
度应高当か、セン出力のノイズ值た減らす 必要が苛引。現在、最大の課題如、眼球、人体

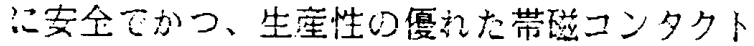
レンス加工法が確立できいことておる。

現在、次心対策:つつき、検討中で芯る。

1）璒性粉体左希士類磁性体などの上り高性能

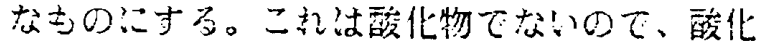
防止策左講し为必要方志。

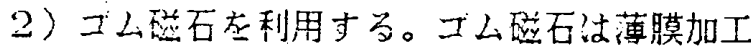
方容易て志る。但し、磁性がやや弱い。

今後の課題として注顔面:対するセンサの取

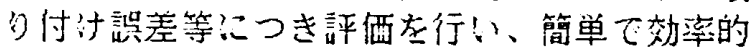

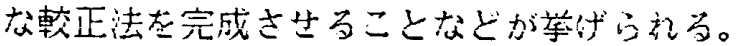
謝辞

帯烪コンタクトレンズの加工䦎してHOY A株式会社、磁性粉体の供給怘関して虫日立金 属株式会社の御協力在頂いたこと在感謝する。

参考文苟

1) 日本平衡神経科学会編：「平衡譏能検査の 実際」，1986，南山堂

2) F. Matsuo, J.F. Peters,et al:"Elec-tr ical Phenomena Associated With Movements 0 $f$ The Ejelid".Electroence phalography and Clinica! Neuro-physiology, 38:507-511,1975 3) J. Schlag, B. Merker M. Schlag-Rey:"Co mparison of EOG And Search Coil Techniques In Long-Term Measurements of The Eve Posi tion In Alert Monkey And Cat", Vision Res.. 23:1025-1030,1983

4 ）張光憲、鎮西清行、舟久保熙康、土肥健純 注か：「小型無拘束眼球運動計獎システムの開 発」，医用電子と生体工学 第25 巻特別号, 1987 
No.30 付 議

\section{東京電機大 佐 久 間 一 郎}

簐験結果では，眼振 $20^{\circ} \sim 40^{\circ}$ の領域では，角 度变位に対するホールセンサ出力变化が得られ ていたが， $0^{\circ} \sim 20^{\circ}$ 付近では，あまり大きな出力 変化が得られず，測定感度が小さいと考えられ るが，その点どのように対策を考えておられる か.
回 答

\section{東京大 鎮 西 清 行}

先生ご指摘の通り，ホールセンサと帯磁コン タクトレンズの間の角度が $0^{\circ} \sim 20^{\circ}$ の場合, 出 力変化が小さく，そのままでは測定分解能が低 下してしまいます。

このため，実際には4つのセンサを用い，あ るセンサが $0^{\circ} \sim 20^{\circ}$ の範囲にあるときは，他の 3つのセンサからの出力を基に演算処理を行う ようにしています。 